\title{
Nucleosome conformational flexibility in experiments with single chromatin fibers
}

\author{
A. V. Sivolob \\ Taras Shevchenko National University of Kyiv \\ 64, Volodymyrska Str, Kyiv, Ukraine, 01033 \\ sivolob@univ.kiev.ua
}

\begin{abstract}
Studies on the chromatin nucleosome organization play an ever increasing role in our comprehension of mechanisms of the gene activity regulation. This minireview describes the results on the nucleosome conformational flexibility, which were obtained using magnetic tweezers to apply torsion to oligonucleosome fibers reconstituted on single DNA molecules. Such an approach revealed a new structural form of the nucleosome, the reversome, in which DNA is wrapped in a right-handed superhelix around a distorted histone octamer. Molecular mechanisms of the nucleosome structural flexibility and its biological relevance are discussed.
\end{abstract}

Keywords: nucleosome, DNA supercoiling, chromatin fiber, conformational flexibility.

Introduction. At the first organizational level chromatin is represented by a chain of nucleosomes, the particles composed of eight histone proteins $-\mathrm{H} 3$, H4, H2A, and H2B (two molecules of each type), and contains $\sim 145$ b.p. of DNA forming $\sim 1.7$ turns of left-handed superhelix on the octamer surface (Fig.1) [1-4]. Nucleosome structure is characterized by a 2-fold symmetry, the dyad axis passes through the interface between two $\mathrm{H} 3$ molecules and the central base pair of nucleosome DNA. The histone octamer consists of three structural elements - $(\mathrm{H} 3-\mathrm{H} 4)_{2}$ tetramer and two $\mathrm{H} 2 \mathrm{~A}-\mathrm{H} 2 \mathrm{~B}$ dimers. The $(\mathrm{H} 3-\mathrm{H} 4)_{2}$ tetramer organizes central $\sim 0.7$ turns of the nucleosomal DNA superhelix, two H2A-H2B dimers provide for the additional DNA wrapping in the nucleosome, thus increasing the number of

(C) Institute of Molecular Biology and Genetics NAS of Ukraine, 2010 superhelical turns to $\sim 1.45$ ( $\sim 125$ b.p.). The interaction of terminal segments of nucleosomal DNA and $\mathrm{N}$-terminal $\alpha$-helices of the $\mathrm{H} 3$ histones (so called $\alpha \mathrm{N}$-extensions, Fig.1) "completes" DNA wrapping around the histone octamer. The complex of DNA and tetramer, a tetrasome (Fig.2), as well as the intermediate complex, a hexasome, containing only one $\mathrm{H} 2 \mathrm{~A}-\mathrm{H} 2 \mathrm{~B}$ dimer, appear in chromatin due to temporary removal of $\mathrm{H} 2 \mathrm{~A}-\mathrm{H} 2 \mathrm{~B}$ dimers in the process of ATP-dependent remodeling of chromatin [5] or transcription elongation [6-9].

Structural dynamics of chromatin is a key element of the system of transcription regulation, determining the availability of regulatory cis-elements for transcriptional factors. The main mechanisms of this dynamics are as follows: 1) ATP-dependent chromatin remodeling - use of energy of ATP hydrolysis to induce intermediate altered structural states of nucleosomes, their repositioning and temporary 


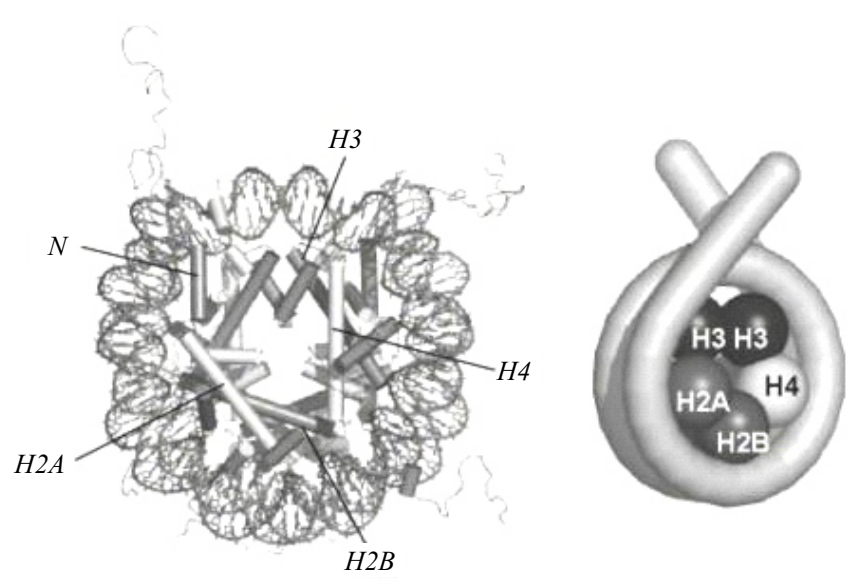

Fig. 1. Nucleosome structure (code PDB 1KX5, sketched image on the right). Molecules of histones and $\mathrm{H} 3 \alpha \mathrm{N}$-extensions are indicated
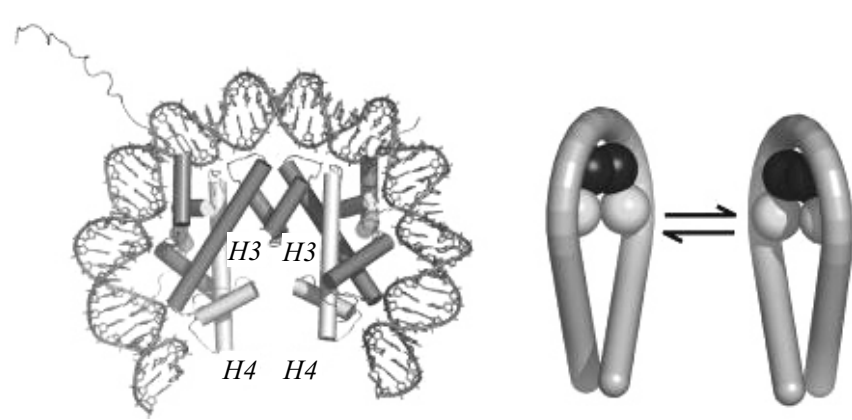

Fig. 2. Tetrasome - tetramer of histones $\mathrm{H} 3$ and $\mathrm{H} 4$ in the nucleosome (from the structure in Fig. 1). On the right - the scheme of structural transition in the tetrasome with the change in its chirality.

removal of histone complexes [10-14]; 2) post-translational covalent modifications of disordered terminal parts of histones (tails), affecting both the efficiency of remodeling and the character of interaction of nucleosomes with numerous non-histone proteins [14-19]. Here any external influence on the nucleosome uses its intrinsic properties - "its own" structural dynamics, conditioned by the peculiarities of intermolecular interactions, stabilizing/destabilizing the structure of this particle.

The region of the nucleosome DNA entry/exit is notable for the least stability level in the nucleosome structure: it is characterized by DNA-histone contacts (with $\mathrm{H} 3 \alpha \mathrm{N}$-extensions and $\mathrm{H} 2 \mathrm{~A}-\mathrm{H} 2 \mathrm{~B}$ dimers) which are less stable than the ones inside the nucleosome [20-23]. Besides, electrostatic repulsion between neighboring turns of the DNA superhelix is an additional destabilizing factor. Therefore, for nucleosome particles reconstituted on linear DNA a spontaneous unwraping of nucleosomal DNA terminal segments was observed, detected by an increase in the availability of nucleosomal DNA for DNA-binding proteins [24-27] and by changes in the efficiency of fluorescent resonance energy transfer (FRET) between donor and acceptor fluorophores, bound to specific sites of nucleosomal DNA and/or histones [28-30].

A chromatin fiber forms loops in a cell nucleus, the ends of which are fixed tight to the nuclear matrix [31-33], therefore, such a loop domain and each nucleosome in the loop are topologically restricted. A series of works on model system - single nucleosome on circular DNA of a small size (minicircle of a contour length of $\sim 350$ b.p.) - presented results on the conformational flexibility of nucleosome as well as sub- and super-nucleosome particles in conditions, which were approximated to the physiological ones $[20,34-42]$. In particular, the existence of several structural forms of the nucleosome was demonstrated: an "open" form, containing $\sim 1.45$ turns of the superhelix, and two "closed" ones -1.7 turns of the superhelix with negative or positive crossing of entry/exit linkers (see Fig.4 below) [20, 35, 36, 40, 42]. Each form fixes its specific value of negative supecoiling in the minicircle, thus relieving a part of torsional stress from DNA, which is not bound to histones. The differences in the free energy between the structural forms, which are rather small comparing to the energy of thermal fluctuations (at the level of 1-2 units of $k T$, where $k$ - Boltzmann's constant; $T-$ absolute temperature), provide for the possibility of conformational equilibrium. This equilibrium may shift to either side depending on the supercoiling level; it may be affirmed that the nucleosome structural states play the role of a buffer, allowing the ring to accumulate torsional stress of either sign easier.

The conformational equilibrium between the nucleosome structural forms depends on the base pair sequence of nucleosomal DNA [40], histone variants [42], and posttranslational modifications of histone tails [35, 36, 38, 39]. In particular, if histones are hyperacetylated then the nucleosome open form becomes the predominant one: a decrease in positive 

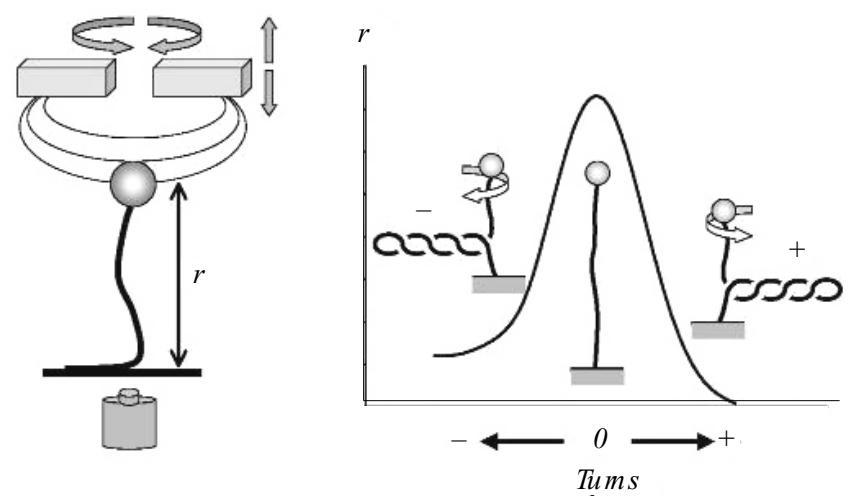

Fig.3 Scheme of magnetic tweezers (see text for details) and a typical picture of relative extension of DNA molecule $r$ as a function of the number of turns of tweezers. Negative and positive plectonemes are shown schematically.

charge of the tails results in the increase in electrostatic repulsion between neighboring turns of the superhelix on the ends of nucleosomal DNA. Since histone acetylation is always in correlation with transcriptional activity, the significance of the open form is evident: firstly, partial unwrapping of nucleosomal DNA enhances its availability for regulatory proteins; secondly, this unwrapping destabilizes the $\mathrm{H} 2 \mathrm{~A}-\mathrm{H} 2 \mathrm{~B}$ dimers, thus facilitating their temporary transfer to intermediate acceptors (histone chaperones), which is always increased during transcription $[43,44]$.

Temporary removal of the dimers leaves a tetrasome on DNA which is also characterized by non-trivial conformational flexibility: the tetrasome superhelix changes its chirality rather easily left-handed "horse-shoe" of the tetrasome becomes right-handed when circular DNA is positively supercoiled (Fig.2) [34, 37-39]. Generally, the results obtained with minicircles (see reviews [45-47]) lead to rather an unexpected conclusion: the presence of histone complexes makes a DNA molecule considerably more flexible, i.e. capable of accumulating supercoiling (torsional stress) of either sign easier.

A similar conclusion was verified and extended in the experiments conducted with single polynucleosome fibers using a magnetic tweezers set-up - a device to apply torsion on a DNA molecule.

The magnetic tweezers [48-50] allow performing real-time nanomanipulations with DNA molecule. Using the magnetic tweezers a DNA molecule (usually from $\sim 5$ to $\sim 50$ thousand b.p.) is attached by one end to the surface of a slide plate in a small chamber - the chamber may have the input of a solution of any composition, an optic microscope objective is located under the chamber (Fig.3). The attachment is made by ligating a special linker to one of the ends using recombinant techniques, the nitrogen bases of the linker are modified by digoxigenin (DIG). A slide plate, covered with anti-DIG antibodies, fixes this end tightly. At the other end of the DNA molecule another linker is ligated, modified by biotin which has high affinity to streptavidin, covering the surface of a bead of 2-3 $\mu \mathrm{m}$ diameter. The bead, attached to the DNA end in this way, is a paramagnetic, affected by the permanent magnetic field created by an electromagnet (Fig.3). The magnet may shift and rotate, as shown in Fig.3. The shift of the magnet creates a stretching force applied to the DNA end, the value of this force depends on the altitude of the magnet above the chamber. The number of rotations of the magnet establishes a specific rotary moment, applied to the molecule end. Thus, there is a torsional rotation of one end with respect the other in either direction. The microscope is used to register two parameters. The first one - average amplitude of oscillations of the bead in the plane, perpendicular to the direction of the stretching force, allows determining the value of the force (in the range of several hundredth to several hundreds of piconewtons): the higher the amplitude of oscillations, the smaller the force. The second parameter is the distance $r$ from the bead to the slide plate: the change in distance, relative to a known focus distance of microscope objective, creates an interference figure around the bead, the character of which allows determining $r$ with the accuracy of several nanometers.

A typical picture of dependence of the distance $r$ on the number of rotations (turns) of the magnet (with insignificant stretching force of $\sim 0.3$ piconewton) is shown in Fig.3. When the number of rotations is zero, the DNA double helix is torsionally relaxed - it has the most favorable for given conditions twist. One rotation of the magnet into the positive direction is overtwisting, and one in the negative direction is untwisting DNA for one turn of the double helix: torsional stress of corresponding sign occurs in the double helix. Rather fast decrease in $r$ while increasing 
the number of turns in both directions is explained by the fact that the rotation of the magnet induces torsional changes in DNA only up to a specific limit - the double helix may accumulate torsional stress only up to specific insignificant value. Once the critical point is achieved, the energy of torsional deformations gets too high which results in the loss of resistance: DNA is supercoiled into a plectoneme (Fig.3). The fact that at some moment torsional rotation should transform into plectonemic coils may be easily proven by twisting a rubber fuse or a simple shoe-lace. The number of turns to start a formation of the plectoneme depends on the ratio of constants of torsional and bending stiffness. The analysis of dependences of the length on the number of turns gives the estimate of the constant of torsional stiffness of DNA $C / k T \sim 75 \mathrm{~nm}[48,49]$ in good agreement with the data of other methods.

Some asymmetry of the curve in Fig.3 (the degree of asymmetry increases along with an increase in stretching force) is explained by local melting of the double helix in case of a great number of negative turns [51]: nevertheless, energy consumption for melting in the least stable areas provides for total energetic benefit, as the destruction of one turn of the duplex "takes" one negative turn. It results in relieving some torsional stress and decreasing the efficiency of formation of plectoneme - a curve of relative extension comes to some non-zero plateau.

Torsional plasticity of polynucleosome fiber. In works $[52,53]$ polynucleosome fibers, containing a different number of regularly positioned nucleosomes, were reconstituted on 36 tandem repeats of 208 (or 190) b.p. of 5S gene sequence of a sea urchin (the repeat has great potential for specific nucleosome positioning). The dependence of the relative extension $r$ on the number of turns of magnetic tweezers for this fiber resembles one for naked DNA - accumulation of torsional stress for maximal extension is changed for the decrease in length while forming a plectoneme. In comparison with naked DNA (a corresponding curve is obtained after the removal of histones by high concentrations of salt) a fiber is considerably shorter and the point of its maximal extension is shifted to the negative side. Both effects (their value is in proportion to the number of nucleosomes in the fiber) are a direct consequence of wrapping of the nucleosomal DNA into left-handed superhelix - each nucleosome "takes" approximately one negative supercoil, and decrease in length is about $\sim 50 \mathrm{~nm}$ ( 150 b.p.) per nucleosome.

There is one more (less trivial) difference between two dependences of the relative extension on the number of turns: a fiber is characterized by a considerably higher torsional plasticity i.e. it is capable of accumulating a significantly higher number of turns without much decrease in the length. A formal analysis gives the estimate of the constant of "torsional stiffness" of polynucleosome fiber as $C / k T \sim 5 \mathrm{~nm}$ which is 15 times lower than the value for naked DNA.

This great plasticity reflects conformational equilibrium between the nucleosome structural forms previously described for the minicircles (Fig.4). Maximal extension of a fiber corresponds to the nucleosome open form - in the conditions of the magnetic tweezers experiment (low ionic strength) this form is predominant due to high electrostatic repulsion between the turns of the nucleosome superhelix. The rotation of nucleosomes around their axes of symmetry and their transition into closed forms with crossed linkers - either negative or positive depending on the direction of rotation of tweezers - allows absorbing a part of torsional stress and, thus, slowing down the formation of a plectoneme, which starts only after the completion of structural transitions. A molecular model of a fiber, providing for possible structural transitions in the nucleosome and their energy (1-2 kT units), allows describing an upper part of the curve, sketched out in Fig.4 in a qualitative way.

Change in nucleosome chirality. The most interesting structural rearrangement takes place in the nucleosome at the moment of establishing a high level of positive torsional stress - after the plectoneme formation is completed. There is a change in chirality of the nucleosomal superhelix, which becomes right-handed in a particle called reverse nucleosome (reversome) [53].

If the number of turns of tweezers into the positive direction is not too large, a reverse rotation results in the extension of a fiber along the same trajectory - both direct and reverse curves of dependence of the relative extension on the number of turns coincide. However, if, after the point when the extension is decreased to 


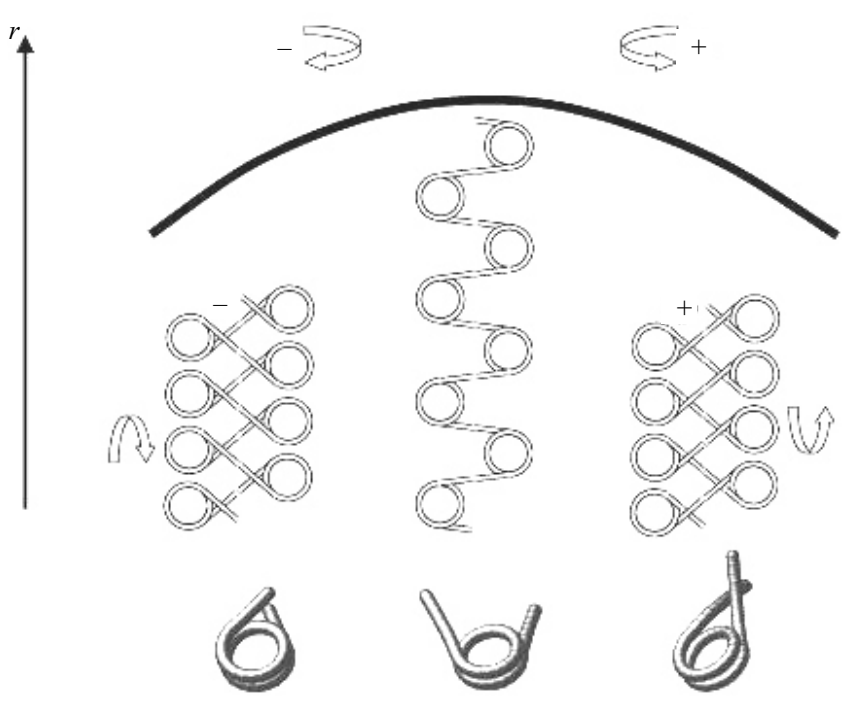

Fig. 4. Response of polynucleosomal fiber to torsional deformation: a curve shows schematically the change in the relative extension $r$ as a function of a number of turns close to maximum (further accumulation of turns of both signs results in a sharper decrease due to the plectoneme formation, see Fig.3). Three structural forms of the nucleosome (below, from the left to the right: closed negative; open; closed positive) provide for "taking in" torsional stiffness due to the rotation of nucleosomes around their axes of symmetry in either direction. Adapted from [52]

zero as a result of the plectoneme formation, approximately 20 more positive turns are performed, then the reverse movement is characterized by a hysteresis: cut-off of plectonemic coils (fiber extension) starts sooner and the length $r$ is larger than that for direct rotation with the same number of turns with respect to the zero point (Fig.5).

This behavior allows two conclusions. First of all, there is a structural change in the nucleosome at the high level of torsional stress, which results in trapping some positive supercoiling by a new particle reversome. The amplitude of the hysteresis (the value of relative shift of two curves in Fig.5) is linearly proportional to the number of nucleosomes in the fiber, the slope of this dependence allows to estimate approximately one positive supercoil, "taken" by the reversome. It is evident that DNA in the reversome forms a right-handed superhelix, which is likely to be a mirror image of the usual left-handed nucleosomal superhelix. Secondly, the hysteresis indicates that two structures are divided by a high energetic barrier - at reverse rotation of tweezers the reversome does not have enough time to re-form into the nucleosome that would be more energetically favorable.

If the reverse rotation is stopped after some number of rotations, there is a long (in dozens of minutes) decrease in the length (a dashed arrow in Fig.5), i.e. there is a transition of the reversome into the nucleosome. The analysis of the transition kinetics allows estimating the altitude of the activation barrier and the difference of free energies between the two states: the free energy of the reversome with respect to the nucleosome is $\sim 10 \mathrm{kT}$, the activation energy is $\sim 30$ $k T$. The latter value almost coincides with that of the free energy of interaction between the two $\mathrm{H} 2 \mathrm{~A}-\mathrm{H} 2 \mathrm{~B}$ dimers and the (H3-H4) 2 tetramer in $2 \mathrm{M} \mathrm{NaCl}$ [54]the activation barrier is related to the necessity of destroying energetically favorable contacts between the dimers and the tetramer in the intermediate state during structural transformation.

Indeed, the only possible way to change the sign of the nucleosomal superhelix is to destroy the interaction of the dimers with the tetramer, to unwrap the superhelix together with the dimers bound to DNA, then to change chirality of the tetrasome, and to establish new contacts of the dimers with the tetramer (Fig.6). Thereafter, the removal of the H2A-H2B dimers from the polynucleosomal fiber (due to treatment with heparin or histone chaperone NAP-1) results in the disappearance of hysteresis: when tweezers are rotating, a remaining tetrasome easily changes its chirality without any activation barriers [53].

Histone-histone contacts in the reversome differ from those in the nucleosome - the $\mathrm{H} 2 \mathrm{~A}-\mathrm{H} 2 \mathrm{~B}$ dimers are bound at the opposite side from the tetramer $(\mathrm{H} 3-\mathrm{H} 4)_{2}$, which is likely to make the main contribution into the difference in free energies between the two structures. Besides, DNA wrapping into the right-handed superhelix results in unavailability of the $\mathrm{H} 3 \alpha \mathrm{N}$-extensions for the interaction with terminal segments - the reversome is likely to be somewhat right-handed reflection of the open form of the left-handed nucleosome.

The biological relevance of the nucleosome conformational dynamics in response to torsional deformations of DNA should first and foremost be related to supecoiling generated by DNA-translocases. Thus, the most evident sources of elastic strains in the 

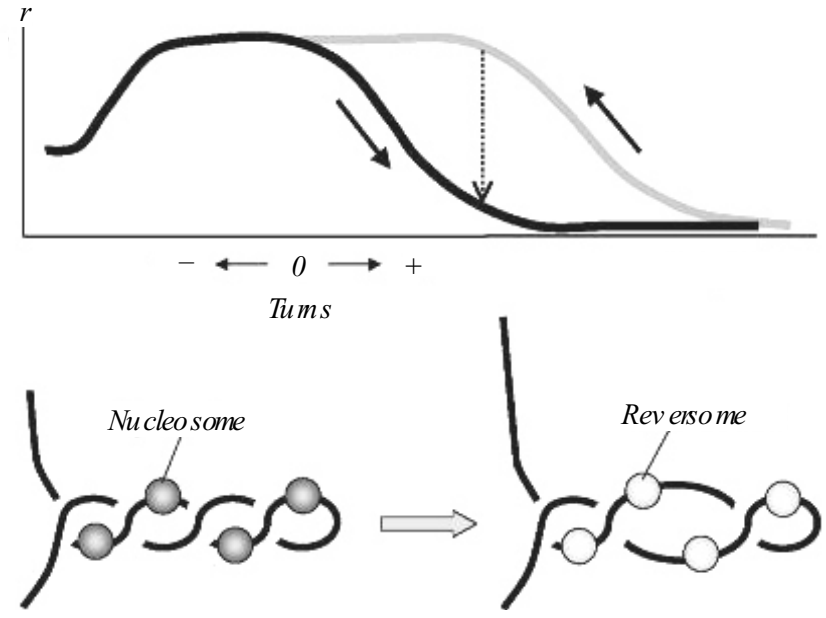

Fig. 5. Top: scheme of hysteresis for accumulation and reverse cut-off of positive torsional stress in polynucleosomal fiber. Solid arrows indicate the direction of the rotation; dashed arrow indicates the direction of slow decrease in the relative extension if the reverse rotation is stopped at some point. Bottom: scheme of structural transformation in the nucleosome, which leads to reversome taking in a part of positive supercoiling. Adapted from [53]

chromatin loop are elongations of transcription and replication, causing positive and negative supercoiling "waves" in front of and behind polymerase complex respectively [55-60]. Torsional plasticity of chromatin, conditioned by its conformational flexibility, is a specific "shock absorber", dampening the abovementioned waves. Here this conformational shock absorber comes into action almost instantly much faster than endogenous relaxing activities of DNA-topoisomerases [60-62].

For instance, negative supercoiling generated by transcription was estimated in vivo in a special reporter construction between two oppositely directed promoters [60]. Attenuation of the supecoiling due to topoisomerases occurs very slowly ( $\sim 30 \mathrm{~min})$, during this period the supercoiling manages to induce non-canonical structural forms of the double helix, recruiting specific transcriptional factors. Therefore, nucleosome conformational flexibility, modulating the level of torsional stress and competing with endogenous relaxing activities and structural transitions in DNA, should be involved into the dynamic control of gene activity.

The role of the nucleosome conformational dynamics in the regulation of transcriptional activity

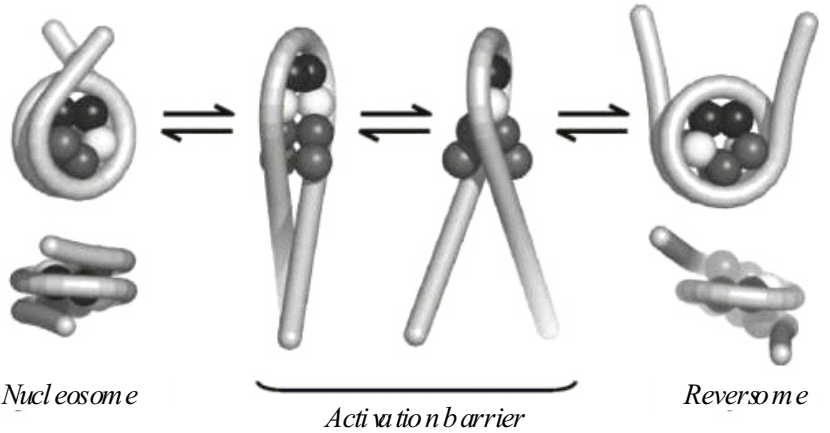

Fig. 6. Scheme of structural transition in the nucleosome with the change in chirality of the superhelix. Histones are indicated as balls, same as in Fig. 1 and 2

becomes more evident taking into account the modulation of this dynamics by such factors as nucleotide sequence of nucleosomal DNA [40], presence of histone variants in the nucleosome [42], and acetylation of histones. In particular, acetylation provides for realization of the open form of the nucleosome $[35,36]$ which, in its turn, facilitates temporary transfer of the $\mathrm{H} 2 \mathrm{~A}-\mathrm{H} 2 \mathrm{~B}$ dimers on histone chaperones [42]. It provides for the formation of the tetrasome, where the transition into the right-handed form is considerably facilitated in case of its acetylation [38, 39].

As for the reversome, it is probably the most efficient tool of damping the positive supercoiling wave in the direction of movement of RNA-polymerase. The polymerase creates a rotary moment of over $8 k T$ per turn of the double helix [63] this energy is quite sufficient to induce the structural transition into the reversome. Here the reversome is both efficient in damping positive supercoiling, providing for the possibility of continuation of transcription elongation, and may be considered as energetically "activated" form of the nucleosome par excellence. The $\mathrm{H} 2 \mathrm{~A}-\mathrm{H} 2 \mathrm{~B}$ dimers, considerably destabilized in the reversome, which are first blockers on the way of RNA-polymerase through the nucleosome [6-9], may be more easily taken off by intermediate acceptors $[43,44]$ or just transferred to neighboring DNA regions [27]. In other words, after reversomes were formed at a large distance, they should be easily transcribed due to destabilized dimers.

Therefore, two supercoiling waves, created by RNA-polymerase itself, assist in performing two 
operations, required for efficient transcription elongation while keeping nucleosome packing of chromatin: in front - the temporary removal of histone complexes is facilitated, behind - negative supercoiling provides for restoring the left-handed nucleosome structure.

\section{А. В. Сиволоб}

Конформационная подвижность нуклеосом в экспериментах с индивидуальными хроматиновыми фибриллами

Резюме

Исследование нуклеосомной организации хроматина приобретаетет все большее значение для понимания механизмов регуляции генетической активности. В настоящем обзоре описаны результаты изучения конформационной подвижности нуклеосом, полученные в экспериментах с магнитным пинцетом устройством, при помощи которого можно сообщать торсионные деформачии олигонуклеосомным фибриллам, реконструированным на индивидуальных молекулах ДНК. Такой подход позволяет обнаружить новую структурную форму нуклеосомы - реверсому, в которой ДНК образует правую суперспираль на поверхности перестроенного октамера гистонов. Обсуждаются молекулярные механизмы и биологическую важность структурной подвижности нуклеосом.

Ключевые слова: нуклеосома, сверхспирализация ДНК, хроматиновая фибрилла, конформационная подвижность.

\section{А. В. Сиволоб}

Конформаційна рухливість нуклеосом в експериментах з індивідуальними хроматиновими фібрилами

\section{Резюме}

Дослідження нуклеосомної організаиії хроматину відіграє все більиу роль у розумінні механізмів регуляиії генетичної активності. У представленому огляді описано результати вивчення конформаційної рухливості нуклеосом, отримані в експериментах з магнітним пінцетом - приладом, за допомогою якого можна індукувати торсійні деформації в олігонуклеосомних фібрилах, реконструйованих на індивідуальних молекулах ДНК. Такий підхід дозволяє виявити нову структурну форму нуклеосоми - реверсому, у складі якої ДНК формує праву суперспіраль на поверхні перебудованого октамеру гістонів. Обговорюються молекулярні механізми та біологічне значення структурної рухливості нуклеосом.

Ключові слова: нуклеосома, надспіралізація ДНК, хроматинова фібрила, конформачійна рухливість.

\section{REFERENCES}

1. Luger K., Mader A. W., Richmond R. K., Sargent D. F., Richmond T. J. Crystal structure of the nucleosome core particle at 2.8 C resolution // Nature.-1997.-389, N 6648.-P. 251-260.

2. Davey C. A., Sargent D. F., Luger K., Mader A. W., Richmond $T$. $J$. Solvent mediated interactions in the structure of the nucleosome core particle at $1.9 \mathrm{C}$ resolution // J. Mol. Biol.2002.-319, N 5.- P. 1097-1113.
3. Richmond T. J., Davey C. A. The structure of DNA in the nucleosome core // Nature.-2003.-423, N 6936.-P. 145-150.

4. Ong M. S., Richmond T. J., Davey C. A. DNA stretching and extreme kinking in the nucleosome core // J. Mol. Biol.2007.-368, N 4.-P. 1067-1074.

5. Boyer L. A., Shao X., Ebright R. H., Peterson C. L. Roles of the histone $\mathrm{H} 2 \mathrm{~A}-\mathrm{H} 2 \mathrm{~B}$ dimers and the $(\mathrm{H} 3-\mathrm{H} 4)(2)$ tetramer in nucleosome remodeling by the SWI-SNF complex // J. Biol. Chem.-2000.-275, N 16.-P. 11545-11552.

6. Kireeva M. L., Walter W., Tchernajenko V., Bondarenko V., Kashlev M., Studitsky V. M. Nucleosome remodeling induced by RNA polymerase II: loss of the $\mathrm{H} 2 \mathrm{~A} / \mathrm{H} 2 \mathrm{~B}$ dimer during transcription // Mol. Cell.-2002.-9, N 3.-P. 541-552.

7. Studitsky V. M., Walter W., Kireeva M., Kashlev M., Felsenfeld $G$. Chromatin remodeling by RNA polymerases // Trends Biochem. Sci.-2004.-29, N 3.-P. 127-135.

8. Li B., Carey M., Workman J. L. The role of chromatin during transcription // Cell.-2007.-128, N 4.-P. 707-719.

9. Kulaeva O. I., Gaykalova D. A., Studitsky V. M. Transcription through chromatin by RNA polymerase II: histone displacement and exchange // Mutat. Res.-2007.-618, N 1-2.P. 116-129.

10. Cairns B. R. Chromatin remodeling: insights and intrigue from single-molecule studies // Nat. Struct. Mol. Biol.2007.-14, N 11.-P. 989-996.

11. Choudhary P., Varga-Weisz P. ATP-dependent chromatin remodelling: action and reaction // Subcell. Biochem.-2007.41.-P. 29-43.

12. Cairns B. R. The logic of chromatin architecture and remodelling at promoters // Nature.-2009.-461, N 7261.-P. 193198.

13. Clapier C. R., Cairns B. R. The biology of chromatin remodeling complexes // Annu. Rev. Biochem.-2009.-78.-P. 273304.

14. Rando O. J., Chang H. Y. Genome-wide views of chromatin structure // Annu. Rev. Biochem.-2009.-78.-P. 245-271.

15. Marmorstein $R$. Protein modules that manipulate histone tails for chromatin regulation // Nat. Rev. Mol. Cell Biol.-2001.2, N 6.-P. 422-432.

16. Narlikar G. J., Fan H. Y., Kingston R. E. Cooperation between complexes that regulate chromatin structure and transcription // Cell.-2002.-108, N 4.-P. 475-487.

17. Turner B. M. Cellular memory and the histone code // Cell.2002.-111, N 3.-P. 285-291.

18. $A n W$. Histone acetylation and methylation: combinatorial players for transcriptional regulation // Subcell. Biochem.2007.-41.-P. 351-369.

19. Shahbazian M. D., Grunstein M. Functions of site-specific histone acetylation and deacetylation // Annu. Rev. Biochem.-2007.-76.-P. 75-100.

20. Goulet I., Zivanovic Y., Prunell A., Revet B. Chromatin reconstitution on small DNA rings // J. Mol. Biol.- 1988.-200, N 2.-P. 253-266.

21. Toth K., Brun N., Langowski J. Chromatin compaction at the mononucleosome level // Biochemistry.-2006.-45, N 6.P. 1591-1598.

22. Mihardja S., Spakowitz A. J., Zhang Y., Bustamante C. Effect of force on mononucleosomal dynamics // Proc. Nat. Acad. Sci. USA.-2006.-103, N 43.-P. 15871-15876.

23. Hall M. A., Shundrovsky A., Bai L., Fulbright R. M., Lis J. T., Wang $M$. D. High-resolution dynamic mapping of histoneDNA interactions in a nucleosome // Nat. Struct. Mol. Biol.2009.-16, N 2.-P.124-129. 
24. Polach K. J., Widom J. Mechanism of protein access to specific DNA sequences in chromatin: a dynamic equilibrium model for gene regulation // J. Mol. Biol.-1995.-254, N 2.P. 130-149.

25. Anderson J. D., Thastrom A., Widom J. Spontaneous access of proteins to buried nucleosomal DNA target sites occurs via a mechanism that is distinct from nucleosome translocation // Mol. Cell. Biol.-2002.-22, N 20.-P. 7147-7157.

26. Li G., Levitus M., Bustamante C., Widom J. Rapid spontaneous accessibility of nucleosomal DNA // Nat. Struct. Mol. Biol.-2005.-12, N 1.-P. 46-53.

27. Hodges C., Bintu L., Lubkowska L., Kashlev M., Bustamante $C$. Nucleosomal fluctuations govern the transcription dynamics of RNA polymerase II // Science.-2009.-325, N 5940.P. 626-628.

28. Muthurajan U. M., Park Y. J., Edayathumangalam R. S., Suto R. K., Chakravarthy S., Dyer P. N., Luger K. Structure and dynamics of nucleosomal DNA // Biopolymers.-2003.-68, N 4.-P. 547-556.

29. Li G., Widom J. Nucleosomes facilitate their own invasion // Nat. Struct. Mol. Biol.-2004.-11, N 8.-P. 763-769.

30. Tomschik M., Zheng H., van Holde K., Zlatanova J., Leuba S. $H$. Fast, long-range, reversible conformational fluctuations in nucleosomes revealed by single-pair fluorescence resonance energy transfer // Proc. Nat. Acad. Sci. USA.-2005.-102, N 9.-P. 3278-3283.

31. Cook P. R., Brazell I. A. Conformational constraints in nuclear DNA // J. Cell Sci.-1976.-22, N 2.-P. 287-302.

32. Benyajati $C$., Worcel $A$. Isolation, characterization, and structure of the folded interphase genome of Drosophila melanogaster // Cell.-1976.-9, N 3.-P. 393-407.

33. Lebkowski J. S., Laemmli U. K. Nonhistone proteins and long range organization of HeLa interphase DNA // J. Mol. Biol.1982.-156, N 2.-P. 325-344.

34. Hamiche A., Carot V., Alilat M., De Lucia F., O'Donohue M. $F$., Revet B., Prunell A. Interaction of the histone $(\mathrm{H} 3-\mathrm{H} 4)_{2}$ tetramer of the nucleosome with positively supercoiled DNA minicircles: Potential flipping of the protein from a left- to a right-handed superhelical form // Proc. Nat. Acad. Sci. USA.-1996.-93, N 15.-P. 7588-7593.

35. Sivolob A., De Lucia F., Revet B., Prunell A. Nucleosome dynamics II. High flexibility of nucleosome entering and exiting DNAs to positive crossing // J. Mol. Biol.-1999.-285, N 3.P. 1081-1099.

36. De Lucia F., Alilat M., Sivolob A., Prunell A. Nucleosome dynamics III. Histone tail-dependent fluctuation of nucleosomes between open and closed DNA conformations // J. Mol. Biol.-1999.-285, N 3.-P. 1101-1119.

37. Alilat M., Sivolob A., Revet B., Prunell A. Nucleosome dynamics IV. Protein and DNA contributions in the chiral transition of the tetrasome, the histone $(\mathrm{H} 3-\mathrm{H} 4)_{2}$ tetramer-DNA particle // J. Mol. Biol.-1999.-291, N 4.-P. 815-841.

38. Sivolob A., Prunell A. Nucleosome dynamics V. Ethidium bromide versus histone tails in modulating ethidium bromide-driven tetrasome chiral transition // J. Mol. Biol.-2000.295, N 1.-P. 41-53.

39. Sivolob A., De Lucia F., Alilat M., Prunell A. Nucleosome dynamics. VI. Histone tail regulation of tetrasome chiral transition. A relaxation study of tetrasomes on DNA minicircles // J. Mol. Biol.-2000.-295, N 1.-P. 55-69.

40. Sivolob A., Lavelle C., Prunell A. Sequence-dependent nucleosome structural and dynamic polymorphism. Potential involvement of histone H2B N-terminal tail proximal domain // J. Mol. Biol.-2003.-326, N 1.-P. 49-63.
41. Sivolob A., Prunell A. Linker histone-dependent organization and dynamics of nucleosome entry/exit DNAs // J. Mol. Biol.-2003.-331, N 5.-P. 1025-1040.

42. Conde e Silva N., Black B. E., Sivolob A., Filipski J., Cleveland D. W., Prunell A. CENP-A-containing nucleosomes: easier disassembly versus exclusive centromeric localization // J. Mol. Biol.-2007.-370, N 3.-P. 555-573.

43. Ito T., Ikehara T., Nakagawa T., Kraus W.L., Muramatsu M. p300-mediated acetylation facilitates the transfer of histone H2A-H2B dimers from nucleosomes to a histone chaperone // Genes Develop.-2000.-14, N 15.-P. 1899-1907.

44. Reinberg D., Sims R. J. de FACTo nucleosome dynamics // J. Biol. Chem.-2006.-281, N 33.-P. 23297-23301.

45. Prunell A., Sivolob A. Paradox lost: nucleosome structure and dynamics by the DNA minicircle approach // Chromatin structure and dynamics: state-of-the-art. New Comprehensive Biochemistry / Eds J. Zlatanova, S. H. Leuba.-Amsterdam: Elsevier, 2004.-Vol. 39.-P. 45-74.

46. Sivolob A., Prunell A. Nucleosome conformational flexibility and implications for chromatin dynamics // Phil. Trans. Roy. Soc. Lond. A.-2004.-362, N 1820.-P. 1519-1547.

47. Sivolob A., Lavelle C., Prunell A. Flexibility of nucleosomes on topologically constrained DNA // IMA Volumes in Mathematics and its Applications / Eds C. J. Benham, S. Harvey, W. Olson, D. W. Sumners, D. Swigon.-New York: Springer, 2009.-Vol. 150.-P. 251-291.

48. Strick T. R., Allemand J.-F., Bensimon D., Bensimon A., Croquette $V$. The elasticity of a single supercoiled DNA molecule // Science.-1996.-271, N 5257.-P. 1835-1837.

49. Strick T. R., Allemand J.-F., Bensimon D., Croquette V. Behavior of supercoiled DNA // Biophys. J.-1998.-74, N 4.P. 2016-2028.

50. Strick T. R., Allemand J.-F., Bensimon D., Croquette V. Stress-induced structural transitions in DNA and proteins // Annu. Rev. Biophys. Biomol. Struct.-2000.-29.-P. 523543.

51. Strick T. R., Croquette V., Bensimon D. Homologous pairing in stretched supercoiled DNA // Proc. Nat. Acad. Sci. USA.1998.-95, N 18.-P. 10579-10583.

52. Bancaud A., Conde e Silva N., Barbi M., Wagner G., Allemand J. F., Mozziconacci J., Lavelle C., Croquette V., Victor J.-M., Prunell A., Viovy J.-L. Structural plasticity of single chromatin fibers revealed by torsional manipulation // Nat. Struct. Mol. Biol.-2006.-13, N 5.-P. 444-450.

53. Bancaud A., Wagner G., Conde e Silva N., Lavelle C., Wong H., Mozziconacci J., Barbi M., Sivolob A., Le Cam E., Mouawad L., Viovy J.-L., Victor J.-M., Prunell A. Nucleosome chiral transition under positive torsional stress in single chromatin fibers // Mol. Cell.-2007.-27, N 1.-P. 135-147.

54. Benedict R. C., Moudrianakis E. N., Ackers G. K. Interactions of the nucleosomal core histones: a calorimetric study of octamer assembly // Biochemistry.-1984.-23, N 6.-P. 12141218.

55. Liu L. F., Wang J. C. Supercoiling of the DNA template during transcription // Proc. Nat. Acad. Sci. USA.-1987.-84, N 20.-P. 7024-7027.

56. Tsao Y.-P., Wu H.-Y., Liu L. F. Transcription-driven supercoiling of DNA: direct biochemical evidence from in vitro studies // Cell.-1989.-56, N 1.-P. 111-118.

57. Rahmouni A. R., Wells R. D. Direct evidence for the effect of transcription on local DNA supercoiling in vivo // J. Mol. Biol.-1992.-223, N 1.-P. 131-144. 
58. Kramer P. R., Sinden R. R. Measurement of unrestrained negative supercoiling and topological domain size in living human cells // Biochemistry.-1997.-36, N 11.-P. 3151-3158.

59. Wang Z., Droge P. Long-range effects in a supercoiled DNA domain generated by transcription in vitro // J. Mol. Biol.1997.-271, N 4.-P. 499-510.

60. Kouzine F., Sanford S., Elisha-Feil Z., Levens D. The functional response of upstream DNA to dynamic supercoiling in vivo // Nat. Struct. Mol. Biol.-2008.-15, N 2.-P. 146-154.

61. Wang J. C. Cellular roles of DNA topoisomerases: a molecular perspective // Nat. Rev. Mol. Cell Biol.-2002.-3, N 6.P. 430-440.
62. Salceda J., Fernandez X., Roca J. Topoisomerase II, not topoisomerase I, is the proficient relaxase of nucleosomal DNA // EMBO J.- 2006.-25, N 11.-P. 2575-2583.

63. Harada Y., Ohara O., Takatsuki A., Itoh H., Shimamoto N., Kinosita K. Direct observation of DNA rotation during transcription by Escherichia coli RNA polymerase // Nature.2001.-409, N 6816.-P. 113-115.

UDC 577.323

Received 11.03.10 